\title{
Article
}

\section{Mastering internal communication: Knowledge foundations and postgraduate education}

\author{
Welch, Mary \\ Available at http://clok.uclan.ac.uk/8171/ \\ Welch, Mary (2013) Mastering internal communication: Knowledge \\ foundations and postgraduate education. Public Relations Review, - (-). ISSN \\ 03638111
}

It is advisable to refer to the publisher's version if you intend to cite from the work. http://dx.doi.org/10.1016/j.pubrev.2013.04.003

For more information about UCLan's research in this area go to http://www.uclan.ac.uk/researchgroups/ and search for < name of research Group>.

For information about Research generally at UCLan please go to http://www.uclan.ac.uk/research/

All outputs in CLoK are protected by Intellectual Property Rights law, including Copyright law. Copyright, IPR and Moral Rights for the works on this site are retained by the individual authors and/or other copyright owners. Terms and conditions for use of this material are defined in the policies page.

\section{CLoK}

Central Lancashire online Knowledge www.clok.uclan.ac.uk

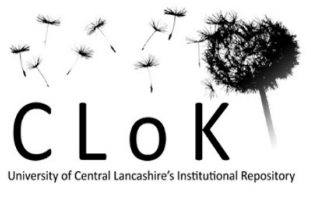




\section{An internal communication knowledge framework}

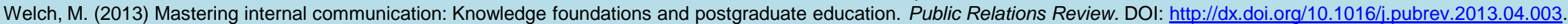

Dr Mary Welch (2014), Lancashire Business School, University of Central Lancashire, Preston, UK.

\section{Knowledge cluster \\ Internal communication knowledge components} categories

Fundamental specialist knowledge

Strategic communication management

Underpinning theory and research

Context and tactical considerations

1. Employment relations

Employee engagement*

$$
\text { Trust* }
$$

Internal stakeholders

\section{Leadership}

- Leadership communication*

- Change communication
5. Communication science

- Business psychology

- Persuasion theory

- Organisational behaviour

- Employee internal communication needs*

- Internal communication effects*

- Informal communication in organisations*

\section{Organisational culture and} context

- Organisational culture

- Organisational context*

\section{Management}

- Communication management

- Interaction with Human

Resources *and Marketing

- Relationship management

- Reputation management

6. Concepts and theory

- Internal communication theory

- The concept of internal communication*

- Communication ethics

9. Issues and crisis communication

- Internal crisis communication

- Internal issues communication
4. Strategy

- Internal communication strategy and objectives

- Internal communication message strategies

- Internal communication campaigns

7. Research and evaluation

- Internal communication evaluation

- Internal communication audits

- Internal communication research
10. Emergent communication methods

- Internal communication methods: social media 